\title{
Does accounting education develop ethical maturity? Evidence from Indonesia
}

\author{
Irsyadillah Irsyadillah ${ }^{\mathrm{a}, \mathrm{b}}$ and Alhashmi Aboubaker Lasyoud ${ }^{\mathrm{b}, 1}$ \\ ${ }^{a}$ Syiah Kuala University, Banda Aceh, Indonesia \\ ${ }^{\mathrm{b}}$ University of Sharjah, Sharjah, United Arab Emirates
}

\begin{abstract}
The purpose of this paper is to provide empirical evidence in relation to the ethical development of students studying accounting in Indonesia. To understand the development of these students' ethical maturity, we examine their perspectives about the purpose of accounting and the objective of business. The paper reports on the results of four focus groups of accounting students who just completed an introductory financial accounting course. The Indonesian context is then used to frame the analysis of the focus groups. Insights from the focus groups reveal a strong notion that the perspectives of students studying accounting in Indonesia were solely influenced by ethical values of Anglo-American capitalism. The ethical values of prioritising shareholder interests over other stakeholders are generally accepted by these students as the nature of accounting and business. The finding suggests that accounting education does not only change the cultural values of students studying abroad in western countries as highlighted by previous studies, it also shapes the ethical values of accounting students educated at home. Thus, this paper concludes that accounting education in Indonesia does not develop students' ethical maturity because they were only inculcated with a single perspective.
\end{abstract}

Keywords: Accounting education, ethical maturity, Islamic values, Indonesia

\section{JEL codes: M41}

\footnotetext{
${ }^{1}$ Corresponding author: Department of Accounting, College of Business Administration, University of Sharjah, P.O. Box: 27271, Sharjah, UAE. Email: alasyoud@ sharjah.ac.ae
} 


\section{Introduction}

It has generally been understood that the traditional worldview of accounting is rooted in neo-classical economics theory (Bento et al., 2017; Stevenson et al., 2018). Therefore, the moral philosophy emphasising the provision of decision useful information mainly to satisfy the needs of shareholders is embedded within accounting education (Boyce \& Greer, 2013). For example, this notion is clearly represented within the syllabi of accounting courses and accounting textbooks as the underpinning framework for business decision making (Ferguson et al., 2009). Given this phenomenon, academics and professionals have made insistent calls for deep reform in accounting education (Wells, 2018; Golyagina \& Valuckas, 2016; Dellaportas, 2015; Chabrak \& Craig, 2013; Sikka et al., 2007). Much criticism has been raised over the fundamental failure of accounting education to problematise and challenge the contingent nature of the discipline on its traditional worldview. A prevalent criticism is particularly made about the failure of the course to acknowledge and challenge the ethical and moral assumptions of the worldview and provide an alternative discourse in accounting education.

While there has been a growing concern over the domination of the mainstream paradigm within accounting education in a western context (Ferguson et al., 2009), criticism over the ideological status quo of accounting education manifested in research papers is totally absent in the context of a developing country, such as Indonesia. Indeed, even in the international accounting literature, this issue has been overlooked in the discussions of the nature and development of accounting education. Nonetheless, there were studies conducted on students studying accounting in western countries such as the US, UK, Canada, Australia, New Zealand touched these issues (Hu et al., 2013; Cho et al., 2008; Saravanamuthu \& Tinker, 2008). These studies suggest that international students of accounting were deeply influenced by the cultural values of Anglo-American capitalism, so much so that they advocate the promotion of the cultural values in their countries. Thus, our research is conducted in the context of Indonesia on students trained at home to address the gap in the literature. Indeed, there is a dearth of knowledge about the area of accounting education research in a non-western context.

The selection of Indonesia for our research was also influenced by the fact that there are many particularities in the Indonesian context including the uniqueness of the state ideology, Pancasila, and the influence of Islamic cultural values in the society. In the light of the above criticisms, and given the particular context of Indonesia, this paper aims to examine whether accounting education in Indonesia develops students' ethical maturity. In so doing, the present study seeks to understand the perspectives of students studying accounting about the purpose of accounting and business. This study would argue that ethical maturity is developed when accounting students are provided space to challege the traditional worldview and exposed to the alternatives. Therefore, it is the focus of this paper to show 
whether such students in Indonesia are shaped by ethical and moral values coming from Anglo-American capitalism promoting maximising shareholder values, or they are also enriched by the local indigenous cultural and ethical values.

Our methodology involves an analysis of focus groups conducted with 24 students of accounting who just completed an introductory financial accounting course at universities in Indonesia. These students were selected to understand how the accounting course starts to inform and shape the perspectives of students studying accounting. Introductory financial accounting course is the first accounting module taken by students studying accounting in Indonesia. Thus, it starts shaping the understandings and beliefs of accounting students. Of course, there are other courses in which students will learn about broader issues of accounting. However, it is not an easy task to change the perspectives of students that have been formed in introductory financial accounting course. The Indonesian context is then employed to frame the analysis of focus groups. Our results suggest that the perspectives of students of accounting about the purpose of accounting and the objective of business are greatly inculcated by an Anglo-American shareholder discourse. Thus, this paper argues that accounting education in Indonesia does not develop students' ethical maturity. This paper argues that the ethical maturity of these students could be developed through the incorporation of the Indonesian indigenous moral and ethical values coming from Islam and Pancasila.

Overall, this paper contributes to the literature by complementing the accounting education research conducted in the western context, which suggests the domination of Anglo-American capitalism in the training of future accountants. The main contribution of this study is to provide some understanding on the extent to which the Indonesian cultures, ideology and philosophy, Islam and Pancasila, influence and enrich accounting students' moral and ethical values. Thus, the insights that will be provided in this paper into the phenomenon of accounting education in Indonesia will provide an important source of knowledge on this topic. Moreover, the evidence presented in this paper has broader implications for the developing, postcolonial and Muslim countries as well as for the accounting education globally. Most importantly, the findings presented in this study can be used as a guidance and inspiration for universities, academics, and authors of accounting textbooks to incorporate materials that may contribute to the development of accounting students' ethical maturity.

The remainder of this paper is structured as follows: Section 2 outlines the theoretical framework used to frame the analysis data presented in this research. Section 3 provides an overview of the existing literature concerning the status quo of accounting education. Section 4 discusses the methodology underpinning this paper. Section 5 presents the findings and discussion of the study. Section 6 draws some conclusions and makes some recommendations for future research. 


\section{Theoretical framework}

\subsection{The development of ethical maturity}

It has become a major concern to improve the ethical reasoning of higher education in accounting because there is so much evidence that accounting students have failed to develop their ethical maturity (Sorensen et al., 2017; Kelly, 2017). It is not unusual nowadays to read news in which we encounter business scandals where accountants have behaved unethically and betrayed the trust of the public (Mele et al., 2017; Lail et al., 2015). This study argues that such failure stems from the reality that accounting education ignores to pay attention to the most fundamental ethical issues. It is important to "acknowledge and address the ethical and moral assumptions that underpin" accounting and "acknowledge alternative frameworks that are guided by different sets of ethical and moral assumptions" (Ferguson et al., 2011. p.12). Indeed, several studies have indicated that accounting education has become a terrain for the socialisation of ideological values of Anglo-American capitalism, whose main objective of business is introduced only to maximise shareholder value (Dellaportas, 2015; Crawford et al., 2014; Collison et al., 2011; Boyce \& Greer, 2013; Kamla \& Haque, 2017; Kamla et al., 2012; Ferguson et al., 2009; Cho et al., 2008; Saravanamuthu \& Tinker, 2008; Sikka et al., 2007).

The main objective of business under Anglo-American capitalist framework was famously declared by Milton Friedman, a Nobel laureate in Economics; that the very foundations of a free market society are based on rejecting the idea of "a social responsibility other than to make as much money for their stockholders as possible" (Friedman, 2002, p.133). Academics in accounting tends "to accept this, unquestioningly, as a natural and self-evident ideology' (Chabrak \& Craig, 2013: 101). Those moral orders of Anglo American capitalism are not necessarily good or bad. However, the paper argues that it would be completely biased not to promote critical learning in accounting education. Students should be provided with alternative ways of exercising their moral will without being constrained by the structures and rules of profit maximisation. Moreover, they should be able to challenge the power asymmetries that underpin the dominant perspective existing within the accounting education (Boyce et al., 2012). This means that accounting students are trained not only to accept, but also to speculate the ideological status quo of accounting. Otherwise, accounting education will surely produce future business leaders who judge a favourable business performance solely on the morality of market capitalism (Boyce, 2014). Therefore, it is the duty of accounting academics to critically engage with such a perspective if we are to begin to engender a fairer society. This is because the dominant moral and ethical assumptions have been spread across accounting education including in places that are culturally shaped by different sets of socio-cultural values, such as Indonesia. 


\subsection{The Indonesian context}

After the declaration of independence on 17 August 1945, there was a lengthy debate between secular nationalists and Muslim leaders related to the state's ideology (Brown, 2003). While the Muslim group insisted that Islam should be adopted as the foundation of the state and Islamic identity should be clearly proclaimed, the secular group strongly opposed the idea of Indonesia as a designated Islamic state. After a prolonged consultation, however, both groups of Indonesian leaders finally agreed and decided that Pancasila should be adopted as the state's ideology (Ismail, 1995). Literally, Pancasila means five principles since it actually consists of five principles. These principles include 'belief in the one supreme God'; 'a just and civilised humanity'; 'the unity of Indonesia'; 'a people's democracy led by wisdom through deliberation and representation'; and 'social justice for the whole of the people of Indonesia'. These five principles should be conceived as an integrated whole because each principle should not be separated from the other principles (Morfit, 1981). In other words, each principle of Pancasila has to be seen with the other four principles. The five principles function as a philosophical basis and a way of life for the Indonesian society (Beck, 2013), and are constitutionally proposed as the basic and fundamental philosophy and ideology of the Indonesian political system and economic model.

Although Pancasila was compromised as the state's ideology, Islam still plays a significant role in the development of the Indonesian society. Azra (2010) explains that Islam has profoundly shaped and is likely to continue to shape Indonesian culture as well as influencing the outlook of its followers. In this sense, Islam provides an important ideological grounding for the majority of the Indonesian people. Therefore, the insights emerging from the Islamic faith and its values and principles should shape the perspectives of Indonesians. The key Islamic principles that make up the individual and collective lives of Muslims include the oneness of God (Tawheed), vicegerency (Khalifah), accountability to God (Ihtisaab), justice (adl), hereafter (Akhirah), knowledge (Ilm), consultation (Shura), scholarly consensus (Ijmaa), independent reasoning (Ijtihat), society at large (Ummah), public interest (Istislah), kindness (Ihsaan) and wisdom (Hikmah) (Kamla et al., 2006; Haniffa et al., 2004; Lewis, 2001). These values and principles govern all aspects of Muslim activities including social affairs, politics and business (El-Kot and Burke, 2014). More importantly, these moral and ethical values should be used to develop and increase the ethical maturity of the Indonesian people.

\section{Literature review}

It has been argued that accounting is a political technology (Araujo et al., 2017), in which policies are controlled by certain elites and dominant ideologies (Arnold, 2009). For Bryer (2012: 513) accounting is a main ideology and a real 'language of 
real life'. Moreover, Cooper (1995) deemed that 'accounting, with its roots in the economics, made it a perfect tool for use by the new right in presenting certain understandings of the world and in closing off alternative understandings' ( $p .117)$. Therefore, it is reasonable to take an analytical position that engages with accounting as a technology that has been occupied by a certain capitalist ideology (Collison, 2003). Indeed, the birth of double-entry bookkeeping has been considered as a significant milestone in the development of capitalism (Chiapello, 2007). Of course, there are people who argue that the worldview should be the moral philosophy of business [accounting] (Sorensen et al., 2017; Vermaelen, 2009; Friedman 2001; Jensen \& Meckling, 1976). This situation is indeed manifested within accounting education, in which western knowledge based on capitalist/neo-liberal values has globally dominated accounting education (Kamla \& Haque, 2017; Jones, 2010). This is in line with what was stated by Freire (1998: 91) that education is not neutral and can be seen as 'a political act'.

The problem is that although accounting education has been greatly socialised and indoctrinated with such single worldview, the aundiences are almost not aware that it performs ideological function (Wells, 2018; Ferguson et al., 2010). In other words, the audiences are not educated to recognise the singularity of views within accounting education. It has been argued that accounting textbooks play a significant role as the most important and justifiable means of promoting the 'legitimated' knowledge, values and cultures (Ferguson et al., 2007). Indeed, studies of management accounting, financial accounting and financial management textbooks recommended in western universities have demonstrated that the accounting texts are constructed using a worldview based on Anglo-American capitalism, which emphasises maximising shareholder value (Wells, 2018; Ferguson et al., 2005). This means that accounting textbooks which are generally regarded to be the unbiased teaching media conveying only facts have become as powerful educational tools to homogenise and generalise moral philosophy of accounting and accounting education.

The inculcation of values that stress only one group of stakeholders should be maximised has certainly influenced ethical and moral development of accounting students. Previous studies have shown that both students and lecturers held similar perceptions that accounting education has generally focused on a worldview that promotes shareholder interests (Dellaportas, 2015; Helliar 2013; Ferguson et al., 2011). Nonetheless, these studies show that not all students were intensively and critically engaged with the dominant worldview in their educational process. They were also not encouraged to be critical towards their recommended accounting textbooks, which merely inculcate the dominat worldview (Boyce et al., 2012). However, Ferguson et al., (2010) indicate that some accounting lecturers were concerned by the dominant worldview within their prescribed accounting textbooks. Thus, they chose to incorporate alternative perspectives within their course, which emphasise not only shareholder's interests but also discussed the 
needs of other stakeholder groups. The lecturers challenged the dominant perspectives through introducing other perspectives in their lectures and tutorials or supplementing their recommended textbooks with additional materials (Ferguson $e t$ al., 2010). As a result, although students' understandings have been shaped by a shareholder worldview, there are some of them who are able to develop their knowledge beyond a shareholder's perspective (Ferguson et al., 2011).

It is important to highlight that the existing literature reviewed above has been all explored in a western context. It is the aim of this paper to fill the void in the literature by examining whether accounting education in Indonesia develops accounting students' ethical attitudes that are only based on the moral philosophy of Anglo-American capitalism or go beyond that to recognise the local indigenous values.

\section{Methodology}

This paper employed focus groups to gather data. This method is not the same as a face to face interview, in which only an interviewer and an interviewee are involved. Focus groups are defined as a form of organised interview in which a number of individuals are involved in a setting (Blackburn \& Stokes, 2000). The participants are those individuals considered by the researcher to be experienced and knowledgeable on the issue being investigated (Gillis \& Jackson, 2002). In this study, focus groups were selected as the main instrument for seeking the opinions, attitudes and perceptions of accounting students. The students' perceptions were sought on two primary issues: how they perceive the purpose of accounting and the objective of business. The students who participated in this study have just completed an introductory financial accounting course. This course is typically the main component and first accounting course that starts forming the ideological perspectives of accounting students.

It is difficult to cover all part of Indonesia to obtain data for this research. Thus, the participants represent only four accounting degrees offered at Indonesian universities. This is a qualitative research that is not trying to make generalisation, so that subjectivity is unavoided. The focus group participants came from three institutions of conventional degrees and one of Islamic accounting programme. This setting was designed to see the differrences and similarities of students' perspectives. Thus, in total, there were four focus groups conducted in this study. The participants were recommended by the lecturers of their introductory financial accounting course. These students were fully consented that although they were recommended by their lecturers, they may refuse to participate in the focus groups. Eventually, six students from the same university consisting of male and female students were put in a group. The number and the gender of the focus group participants in each university are depicted in table 1 below. 
Table 1. Focus group participants in each university

\begin{tabular}{ccccc}
\hline & $\begin{array}{c}\text { University A } \\
\text { (Conventional } \\
\text { Degree) }\end{array}$ & $\begin{array}{c}\text { University B } \\
\text { (Islamic Degree) }\end{array}$ & $\begin{array}{c}\text { University C } \\
\text { (Conventional } \\
\text { Degree) }\end{array}$ & $\begin{array}{c}\text { University D } \\
\text { (Conventional } \\
\text { Degree) }\end{array}$ \\
\hline Female & 3 & 3 & 2 & 3 \\
Male & 3 & 3 & 4 & 3 \\
Total & 6 & 6 & 6 & 6 \\
\hline
\end{tabular}

The focus groups were conducted in Indonesian as this is the language of the researcher and the participants. In each case, before focus group was started, the researcher informed the participants about the objective for undertaking the focus group (Gillis \& Jackson, 2002). Then, they were asked for permissions to record the discussion. None of them objected the discussion to be recorded. On average, the focus groups were completed in one hour, in which a set of open-ended questions covering the areas of interest were asked to the students. By having a list of questions, the researcher could ask the same questions to all focus groups, but, the researcher could also follow up on a question if an extended response seemed to be required. This means themes or topics that came up in the discussion could be discussed and followed up in more detail.

In analysing the focus groups, all tapes were firstly transcribed by independent transcribers. Before handing the tapes to the transcribers, the researcher had already labelled each tape with a code. Therefore, the confidentiality of focus group participants was upheld. When they finished transcribing all the tapes, the written transcriptions were then returned to the researcher, and independent transcribers would remove all data related to this study including the tapes and transcripts. Afterwards, the researcher played each tape again and checked for errors and inaccuracies. The researcher also added some observational data that had been noted during the focus groups, particularly with respect to the nuances of the focus group process. These include nonverbal communication, such as gestures, tone and behavioural responses. It is important to underline that the independent reviewers could not trace the persons talking in the tapes because the names of the focus group participants and their institutions were not recorded.

Once the transcripts were finished, they served as the basis for further analysis. The content of discussions was examined by re-reading all transcripts one by one to discover the meanings that explained how students perceive the purpose of accounting and the objective of business. Themes and patterns had to be established to be able to answer the research question. For that reason, firstly, the researcher re-read each transcript one by one until all four transcripts were completed. During the process, the researcher highlighted substantive statements (those that really make a point) and discarded other materials deemed irrelevant to this research (Gillham, 2000). If the researcher could not understand certain parts of the transcript, the researcher would play the interview tape again to ensure the 
accuracy of interpretation. After that, those highlighted statements were reanalysed to determine a set of themes and patterns. These patterns were not only established by comparing the discussion between focus groups, but they were also extracted from comparing the statements provided by each participant within a focus group. Finally, the analysis produces a final set of themes and patterns that became the basis for discussing the problem under investigation in this study.

\section{Findings and discussion}

This section explores the views of students on accounting and business, with the purpose of bringing greater insight to whether the alternative perspective and local socio-cultural context forms part of their understanding, or if that is subsumed by a western perspective central to the dominant worldview permeating accounting education.

\subsection{The purpose of accounting}

The student participants in each focus group were first asked what they perceived to be the purpose of accounting. They all were in broad agreement that accounting functions as a tool to record and report financial information to the users. For example, the response from Student C4, was fairly typical, indicating that:

"The purpose of accounting is to record and report economic events of a business corporation which enables the users to evaluate the performance of the corporation for making business decision."

Students in the second focus group, who were studying an Islamic accounting degree, shared the same point of view. However, they emphasised that keeping the records of financial and business transactions is a requirement under Islamic principles. For example, Student B3 stated:

"For Muslim, making a record of business activities is really important. Therefore, accounting is not only an objective business tool, but it is also mandated by Islamic religion."

Other students of the Islamic accounting degree similarly showed a very strong belief that Islam requires any business transactions to be objectively recorded and reported, and accounting was considered by the students as the tool to fulfil this role. For example, Student B4 explained that:

"the main purpose of accounting is to correctly maintain and report business activities...If there are businesses or any other non-business organisations, which do not employ accounting, I am totally sure they will not live for a long time." 
The students of conventional accounting programmes held the same view, that accounting may help interested parties to obtain reliable financial information, but they did not relate it with religion. For example, Student A3 noted:

"For me, the role of accounting is to produce qualified and accurate financial information. Yes, in order to be objective and reliable, corporations need accounting. For example, by employing accounting system, corporations may clearly show how they make and spend their money."

It is clear that for conventional accounting students, accounting is a reliable instrument to evaluate organisations' accountability to humans, whereas for Islamic accounting students, accounting enables organisations to be accountable not only to humans but also to God. The arguments put forward by the Islamic accounting students are in line with the literature of Islamic accounting (Kamla et al., 2006). This finding is not surprising, though, since they were undertaking an Islamic accounting programme, in which they should have been exposed to Islamic perspectives on accounting. What surprised me most is that regardless of this distinction, the general views of both conventional and Islamic accounting students clearly represent a very traditional, western Anglo-Saxon capitalist perspective. This argument is made on two counts, first because both groups of students explicitly regarded accounting as the non-problematic practice of recording financial or monetarily measurable events; and second, because they considered accounting as an objective science/ instrument that produces reliable/ honest financial information for investment decision usefulness (Jones, 2010). In neither case did they engage with the underlying capitalistic framework of accounting in terms of both how it is practised and how it is taught. The general understanding of accounting by the student participants is certainly different from non-mainstream or social accounting perspectives, in which the triple bottom line of financial, social and environmental consequences of business activities is integrally considered as the concern of accounting (Bento et al., 2017).

\subsection{The users of accounting information}

The student participants were asked to identify the users of accounting information. According to the IASCF, (1989) the users of accounting information include potential investors, employees, lenders, suppliers and other trade creditors, customers, governments and their agencies and the general public (International Accounting Standard Committee Foundation, 1989). All students agreed that the users of accounting information include internal and external parties, and by internals all of them meant management. However, they differed in terms of who are the most in need of accounting information prepared by business enterprises to external parties. For conventional accounting students, they were aligned in this aspect, whereby, in their view, the shareholders were regarded as the most 
important group to whom accounting information should be prepared. For example, Student A3 explained:

"In my opinion, the most important users are shareholders...It is useless to provide information to [the] general public as not all people invest in the firm."

For student (B6) of Islamic accounting degree, shareholders were also regarded as the most important users. Conversely though, for the majority of the Islamic accounting students, all users were considered equal. For example, Student B3 commented:

"The purpose of accounting is to provide financial information to those in need of the information. They include internal and external users. The internals are the managements while the externals are the stakeholders, which need to be treated equally."

To those participants who considered shareholders as the most important users, we queried the preeminent position of shareholders. In this respect, Student D5, for example, from a conventional degree pointed out that:

"They have invested their money into the firms as for the capital. If the money is kept in a bank, they will regularly receive the interest. Therefore, their wealth should get the same when they put it in corporations. In this regard, accounting plays a role in preparing information to them in order to be able to get an idea about the position of their wealth."

In the same fashion, Student B6 commented that:

"When salary of employees is time to be paid, although the firms suffer a loss, shareholders still need to find a way to pay their salaries. Therefore, shareholders should be regarded as the most important users as the ultimate responsibility of the business organisations is on them."

The preceding discussions of perceptions about the users of accounting information convey that the general understanding of student participants echoed a conventional view of providing accounting information. They explicitly mentioned that shareholders are the most important users of accounting information. Similarly, Ferguson et al. (2011) reported, that accounting students in the UK believed that accounting information should be prioritised to shareholders. Collison et al. (2011) also acknowledged that accounting students in Japan believed that accounting information should be predominantly prepared for shareholders. However, a small group of students who studied for an Islamic accounting degree brought in an understanding departing from a narrow conventional perspective of accounting. In that respect, the students viewed accounting information as being pertinent to all stakeholders. Those students seem to have developed a sense of 
understanding that all users of accounting information have equal rights with respect to their access to accounting information. This finding is certainly not reflective of or consistent with the mainstream accounting textbooks prescribed to the students. Thus, one could point to the substantive influence of their lecturers.

In general, the participants were aware of internal and external users of accounting information, but they just focused on shareholders. Therefore, they were asked to list other users. In doing so, the student participants listed three other users including lenders, customers, and governments. They did not mention employees and the general public. Student A2 justified the view that accounting information is important for creditors by saying 'they have provided loans to companies', while Student $\mathrm{C} 1$ argued that 'governments fund the corporation, thus they deserve to be prioritised when financial information is prepared'. With respect to argument about governments, it shows that the student was aware that in Indonesia governments still predominantly own some public corporations. Therefore, in referring to 'government' the students could be said to be meaning the 'shareholders'. In this sense, again, the student shared a very traditional mainstream view of accounting of prioritising shareholders. In terms of customers, Student D6 pointed out that:

"Customers are very concerned with the quality of goods produced by corporations. They always hope that corporations increase the quality of their products. If corporations have good financial performances, it means the corporations are able to produce good quality products. Therefore, financial information is also useful for customers."

Given the fact that none of student participants refer to either the employees or the general public in their discussion, they were specifically asked about these two users. In this respect Student C4 responded:

"In my opinion, accounting is just for certain people because not everyone is able to understand accounting. It is something difficult to understand by general people including employees. It is only accounting people [who have learnt accounting] understand information provided by accounting."

With regard to general public, Student C1, for example, commented:

"Corporations are very often contributing to the general public through CSR [corporates social responsiblity] programmes. The information about the money spent for the CSR could be included in financial statements. Thus, people may get full information regarding how much the firms contribute to society."

The students from these three conventional accounting programmes showed awareness that customers and the general public were interested in such information as the quality of products and the social activities of business organisations. However, the nature of their understanding suggested that financial 
statements are the only way to capture and report business activities. In other words, these business activities need to be defined in accounting terms and quantified in monetary values in order to be able to report to the users; and then only to a closely proscribed set of users. Indeed, previous studies have suggested that students have difficulty in not predicating accounting upon monetary values of numerical quantification (Jones, 2010). More importantly, previous studies, such as that of Birkin (1996: 237), has highlighted that 'numbers are useful abstractions but they do not have the ability to contain the complex and interdependent series of events attendant upon any action.' In the context of this study, therefore, students did not have an understanding that there are alternative accounting reports that may be used to capture and report the social, environmental and ethical consequences of business activities, such as sustainability reports or integrated reports. This lack of understanding was also evident in the group of Islamic accounting students. They were also not sure how to construct corporate reports that accommodate the interests of all stakeholder groups. They seemed only to know of financial statements as the medium for corporations to report their business activities.

\subsection{The objective of business}

Having understood the knowledge of the student participants regarding the purpose of accounting and the users of accounting information, as discussed in the previous two sections, now, the students' perceptions about the objective of business is reported. The aim is to explore whether students were influenced by the mainstream worldview of business as dominantly promoted in accounting education or, they were also aware of alternative understandings that may be influenced by the Indonesian local socio-political and cultural contexts. First of all, the student participants were asked about the purpose of business. All participants, from both conventional and Islamic accounting programmes, explicitly expressed that business is built simply to make profits. For example, Student C6 explained:

"Business exists to make profits. It is not similar to social organisations, such as NGOs which are built to achieve social objectives."

Student B4, taking an Islamic accounting degree, also agreed with the above statement, noting:

"Business is set up to make profits ... Yes, the primary objective of any business organisations is to make profits."

Even though Student A1 did not precisely say that business exists to create profits, he could be understood to mean the same when saying:

"We build a business in order to have a happy life, because it creates wealth for us." 
As they conceived the objective of business to create profits which is in line with the view of Milton Friedman, they were asked about in whose interest business organisations are operated. This question was asked in order to understand how the student participants conceived the way profits made by business organisations should be distributed. Again, the participants were in general agreement that business organisations should be operated to satisfy the interests of shareholders. In this respect, an Islamic accounting Student (B2), for example, pointed out that:

"It is for shareholders. Yes, the corporations should be run in the interests of shareholders, because they are the ones who invested the money and started the corporations."

Similarly, Student D6 explained:

"The profits made by business organisations should go to shareholders as they are the real owners of businesses."

The statements above clearly situate the views of the student participants firmly within the traditional or western perspective of business as they regarded that the sole purpose of any business organisations has to be the profit maximisation, and the profits made should be distributed to the owners of the business, the shareholders. In this sense, their perceptions are completely in line with their previous understanding that the principal users of accounting information are shareholders. In addition, this view accords with the findings of earlier studies conducted in accounting students at the UK and Japanese universities (Collison et $a l ., 2011)$. They pointed out that although the process taking place in accounting education did not significantly change the understanding of the UK students about the objective of business, because of the rhetoric of shareholder value is ingrained in the Japanese accounting and finance discourse, the education process has indeed altered the perspective of Japanese students to be more in line with the AngloAmerican worldview. In the context of this study, therefore, it is legitimate to assume that the understandings of the students may have also been shaped by accounting education, in a sense that the prescribed textbooks are the major sources of the students' knowledge. Therefore, it could be argued that the prescribed textbooks have become the medium for the spread of Western perceptions and values in the Indonesian accounting education.

In the Indonesian context, the western business perspective displaces more contextual cultural and ideological values concerning the Indonesian people, Islam and Pancasila. With respect to Islam, for example, Kamla et al. (2006: 248) explained that 'concerns for the environment are deeply rooted in all fields of Islamic teaching and culture', and that this approach emphasises the importance of social justice and poverty eradication. However, respondents did not show any awareness of the principle of equitable and fair income and wealth distribution in society, and the commitment to take care of the Earth and the environment as imperative, rather than emphasising the creation of profits to maximise the flow of 
dividends to owners. Instead from the evidence that has been gathered for this study, it can be argued that the participating students are deeply imbued with the philosophy of greater shareholder-orientation regarding the distribution of income and wealth, avoiding the social and environmental dimension of business responsibility. More importantly, what struck this study most is that the structure of the Islamic accounting programme did not motivate students to develop an alternative, Islam-inspired understanding of business that is different from the Western one. Instead, the findings indicate that the programme failed to promote either Islamic aspirations or indigenous cultural and ideological values. As a result, this discussion makes it apparent that the Western culture promoting the profit motive and the primacy of wealth creation for the benefit of shareholder alone, maintains its hegemony in its education realm (Ferguson et al., 2010).

Although all student participants expressed their belief that the basic obligation of business is the economic one, which means that business is underpinned by the capitalistic view of maximising profits (Collison, 2003), there were six students who were somehow aware of the potential for social engagement by business organisations. These students were all from conventional accounting groups. It is important to note that this alternative view became apparent after the researcher had challenged them by asking if making profit was the only role of business organisations. This suggests that their fundamental view was still in line with the conventional perspective, although they tried to provide an alternative one when asked to consider that possibility. Nevertheless, although the researcher challenged the Islamic group in the same way, the researcher still did not receive any alternative view considering the social role of business. With respect to the notion of the alternative view, Student B5, for example, explained that not all business is motivated by profit-making, there are some businesses that are motivated to produce an innovation:

"There is also business motivated to produce goods that do not exist yet or to improve the quality of the existing products that may be very useful for society. For example, the developers of Google, I think when they first developed the search engine, it was not motivated to make profit, but instead to create new innovations which would beneficial to society. Another example, Apple, I think they did the same. They at first just wanted to improve the quality of computer products."

Similarly, Student D4 noted that the purpose of business is also:

"...To meet the needs of society. If, for example, certain products are not provided by business, how then human beings could fulfil their needs." 
It appears that these students believed that by being an innovator, business corporations may solve problems and meet social needs. On the one hand, the statements above indicate a departure of a/ the business understanding from the conventional perspective, and moving away from the worldviews manifest in their prescribed textbooks, in which the business role is propagated and limited to maximising profits. Indeed, for example, the invention of the Internet itself could be regarded as the greatest achievement of humankind, because, for example, we can now do research from almost anywhere, whereas before we had to go to a special location, such as a library. This development means that such innovation can ease the life of human beings (professional researchers or otherwise), by bringing access to knowledge to many more people/ academics; and that business organisations play a role in making it easy (social contributions). On the other hand, however, it could be said that the students' views were still trapped in a traditional understanding, because they did not underline that the products could do something other than maximise the wealth of shareholders. It is generally understood that business organisations such as Apple and Samsung are well known for their innovations, but we would say that the innovations, rather than being put to use to enhance the lives of all, are instead used essentially to maintain and increase the profits of the corporations, thus increase the wealth of shareholders. Therefore, it can be said that the students were still influenced by the philosophy of Anglo-American capitalism.

Likewise, but in a different case, for two participants in the first focus group, business may also contribute to society through providing jobs. In expressing this view, they offered an understanding that business is capable of serving the common good. Student A5 commented:

"When a business organisation is set-up, it could not be operated alone. It needs employees to operate the business. For example, some businesses are built in Indonesia because wages are still very low compared to other countries. However, I am sure that they are built in Indonesia, not only to operate at lower cost, but also to create jobs for poor people. This means Indonesian people would have more opportunity to work in the true form of business organisations. Otherwise, we could just work in home-based businesses."

Similarly, Student A6 explained:

"Yes, I think people are better to work in business organisations because they will get better monthly salary. In addition to that they will get more compensations if the corporations make more money. Nowadays, I see people working in corporations are paid large bonuses. They will also get promoted. It should not be denied that this is some kind of contribution made by business organisations to society." 
Although they claimed that providing job opportunities is a sign of taking care of society, for us, the statements made by student A5 and A6 provide clear evidence of the perspective influenced by the shareholder-value mantra. In the case of Student A5, he still put profits (by paying lower labour costs) before society. By doing this, businesses actually exploit people rather than serving them. In the case of Student A6, society (employees) will get better pay or obtain more benefits if corporations make more money. The fact is, however, that employees are provided with their benefits after the shareholders' interests are satisfied, and those benefits do not necessarily reflect any increase in the profits made by companies. Again, this perspective reflects the belief that shareholders come first.

Besides creating jobs, Student A5 also believed that the general public benefits if business organisations are established, especially those people living close to the corporation sites. Nevertheless, again, the profit-first ideology is also inherent here:

"In general, business exists to make profits for its owners. However, it may beneficial to local communities as well. I think if local communities are satisfied, corporations will also gain benefits."

Likewise, the obsession with profit maximisation is ingrained in the comment made by Student C3 below when she considered the importance of prioritising the interests of customers if business organisations want to succeed:

"Customers are really important, because if they are not interested to purchase products offered by the corporations, they will not be developed and make profits."

On the whole, although Indonesia, with its Pancasila and Islamic traditions, means that Indonesians share contextual beliefs and cultures that are different from the West, most students still expressed understanding of business through the perspective of a Western traditional conception. In other words, maximising shareholder wealth through the creation of profits still rules the day within the Indonesian accounting education. As such, in tandem with the purpose of accounting, it is appropriate to say that the students expressed their opinion about the objective of business to be in line with the philosophical conception worshiped within their prescribed textbooks. In addition, the researcher would argue that the profit-driven ideology that is predominant in both prescribed textbooks has contributed to the hindrance of the students' ability to engage with alternative perspectives. There was an awareness of social responsibilities of business organisations, but the students were still deeply influenced by the shareholdervalue mantra. They failed to see the bigger picture and the benefit of balancing the economic and social roles of business corporations; let alone placing emphasis on the latter. 


\section{Conclusion}

The purpose of this paper is to better understand the ethical maturity of students of accounting in Indonesia. Results from the focus groups provide evidence that the students' ethical and moral development is heavily influenced by the mainstream worldview. It seems that the educational process offers no alternative views on the practice and purpose of accounting other than the Anglo-American capitalistic one. Therefore, it can be argued that based on the findings and their analysis, accounting education in Indonesia has been driven by hegemonic forces, which socialise, or more appropriately, indoctrinate Indonesians, with the dominant worldview, the maximising shareholder value paradigm (Pento et al., 2017). This assertion is based on the evidence presented in this paper, whereby the participating students were, in essence, fully directed by the mainstream accounting perspective, to enrich their moral philosophy (Ferguson et al., 2009). This is intriguing as this research was conducted with students studying accounting domestically. This means accounting education does not only change the cultural values of students studying accounting overseas, but it also shapes the ethical and moral values of students educated accounting at home (Kamla et al., 2012; Collison et al., 2011).

The mainstream worldview was clearly manifested in students' understandings of the purpose of accounting and the objectives of business. The participating students held a very strong view that accounting should provide economic/ financial information, with which shareholders may make business decisions. In addition, the students maintained that the role of business is to make profits for shareholders, as they are the owners and the ultimate groups of people who are responsible for the business. Therefore, by synthesising the research with others working in this area of research (Hu et al., 2013; Chand et al., 2012; Ferguson et al., 2011; Cho et $a l ., 2008)$, one could argue that accounting education in Indonesia explicitly propagates the Anglo-American paradigm because the 'natural' socio-cultural state of Indonesia is not Anglo-American. This perspective could be seen as providing an explanation for the students' views, being so abstract with regard to whom business activities should benefit. In the context of Indonesia should be guided by Pancasila and Islam rather than by capitalism. This reality may have been greatly contributed to by the way accounting education is run in Indonesia. Thus, it can be assumed that accounting textbooks which have been disclosed by several studies of promoting Anglo-American capitalism have driven accounting education in Indonesia further towards the western model of accounting. Textbooks may have consolidated western values within the Indonesian accounting education instead of the indigenous values that are best expressed by Pancasila and Islam.

It is also clear that even students studying the Islamic accounting programme appear to have been seduced by much of the dominant view. Therefore, one aim of this paper is to raise awareness of the impact of western accounting education in 
non-western countries. The political and economic bases of the accounting education tradition should not displace the attention of students from their local wisdoms that Indonesia is mostly influenced by Pancasila and Islam. The fact that there was only a small number of students who reflected Islamic views in their understandings of accounting and business should be a matter for concern, since it is discernible that their views were greatly influenced by the paradigm promoted in western accounting education (Boyce \& Greer, 2013). As the perspective of the students who participated in the focus groups were not different from the mainstream perspective within accounting, it can be said that accounting students are only shaped by ethical and moral values coming from Anglo-American capitalism (O'Connel, 2017; Ferguson et al., 2005). In this sense, accounting education in Indonesia does not develop ethical maturity, which can be done through promoting alternative perspectives, such as the ethical and moral values coming from Islam and Pancasila. Therefore, to further understand the findings in this study, future research could investigate the textbooks, teaching materials and other learning resources used in accounting education and their impact on students' ethical maturity. The perspectives of people involved in accounting education could also be obtained regarding the homogenisation of accounting education.

\section{References}

Araújo, W. G., Rodrigues, L. L. \& Craig, R. (2017) "Empire as an imagination of the centre': The Rio de Janeiro School of Commerce and the development of accounting education in Brazil", Critical Perspectives on Accounting, vol. 46: 38-53

Arnold, P. J. (2009) "Global financial crisis: the challenge to accounting research", Accounting, Organizations and Society, vol. 34(6): 803-809

Azra, A. (2010) "Cultural pluralism in Indonesia: Continuous reinventing of Indonesian Islam in local, national, and global contexts", Paper presented at the 10th Annual Conference on Islamic Studies (ACIS), 1- 4 November 2010, Banjarmasin

Beck, M. C. (2013) "Contemporary systems sciences, implications for the nature and value of religion, the five principles of Pancasila, and the five pillars of Islam", Dialogue and Universalism, vol. 4(1): 1-41

Bento, R. F., Mertins, L. \& White, L. F. (2017) "Ideology and the balanced scorecard: An empirical exploration of the tension between shareholder value maximization and corporate social responsibility", Journal of Business Ethics, vol. 142(4): 769-789

Birkin, F. (1996) "The ecological accountant: from the cogito to thinking like a mountain", Critical Perspectives on Accounting, vol. 7(3): 231-257 
Blackburn, R. \& Stokes, D. (2000) "Breaking down the barriers: using focus groups to research small and medium-sized enterprises", International Small Business Journal, vol. 19(1): 44-67

Boyce, G. (2014) "Accounting, ethics and human existence: Lightly unbearable, heavily kitsch", Critical Perspectives on Accounting, vol. 25(3): 197-209

Boyce, G. \& Greer, S. (2013) "More than imagination: Making social and critical accounting real", Critical Perspectives on Accounting, vol. 24(2): 105-112

Boyce, G., Greer, S., Blair, B. \& Davids, C. (2012) "Expanding the horizons of accounting education: incorporating social and critical perspectives", Accounting Education, vol. 21(1): 47-74

Brown, C. (2003) A Short History of Indonesia: The Unlikely Nation?, New South Wales: Allen \& Unwin.

Bryer, R. (2012) "Americanism and financial accounting theory - Part 1: Was America born capitalist?", Critical Perspectives on Accounting, vol. 23(7): $11-55$

Chabrak, N. \& Craig, R. (2013) "Student imaginings, cognitive dissonance and critical thinking", Critical Perspectives on Accounting, vol. 24(2): 91-104

Chiapello, E. (2007) "Accounting and the birth of the notion of capitalism", Critical Perspectives on Accounting, vol. 18(3): 263-296

Cho, C. H., Roberts, R. W. \& Roberts, S. K. (2008) "Chinese students in US accounting and business $\mathrm{PhD}$ programs: Educational, political and social considerations", Critical Perspectives on Accounting, vol. 19(2): 199-216

Collison, D. J. (2003) "Corporate propaganda: its implications for accounting and accountability", Accounting, Auditing \& Accountability Journal, vol. 16(5): 853-886

Collison, D., Ferguson, J., Kozuma, Y., Power, D. \& Stevenson, L. (2011) "The impact of introductory accounting courses on student perceptions about the purpose of accounting information and the objectives of business: A comparison of the UK and Japan", Accounting Forum, vol. 35(1): 47-60

Cooper, C. (1995) "Ideology, hegemony and accounting discourse: a case study of the National Union of Journalists", Critical Perspectives on Accounting, vol. 6(3): 175-209

Crawford, L., Helliar, C., Monk, E., \& Veneziani, M. (2014) "International Accounting Education Standards Board: Organisational legitimacy within the field of professional accountancy education", Accounting Forum, vol. 38(1): $67-89$

Dellaportas, S. (2015) 'Reclaiming 'Sense' from 'Cents' in Accounting Education", Accounting Education, vol. 24(6): 445-460

El-Kot, G. \& Burke, R. (2014) "The Islamic work ethic among employees in Egypt", International Journal of Islamic and Middle Eastern Finance and Management, vol. 7(2): 228-235

Ferguson, J., Collison, D., Power, D. \& Stevenson, L. (2005) "What are recommended accounting textbooks teaching students about corporate stakeholders?", The British Accounting Review, vol. 37(1): 23-46 
Ferguson, J., Collison, D., Power, D. \& Stevenson, L. (2007) 'Exploring lecturers' perceptions of the emphasis given to different stakeholders in introductory accounting textbooks", Accounting Forum, vol. 31(2): 113-127

Ferguson, J., Collison, D., Power, D., and Stevenson, L. (2009) "Constructing meaning in the service of power: An analysis of the typical modes of ideology in accounting textbooks", Critical Perspectives on Accounting, vol. 20(8): 896-909

Ferguson, J., Collison, D., Power, D., \& Stevenson, L. (2010) "The views of 'knowledge gatekeepers' about the use and content of accounting textbooks", Accounting Education: An International Journal, vol. 19(5): $501-525$

Ferguson, J., Collison, D., Power, D. \& Stevenson, L. (2011) "Accounting education, socialisation and the ethics of business", Business Ethics: A European Review, vol. 20(1): 12-29

Freire, P. (1998) Pedagogy of the Oppressed, Continuum, New York

Friedman, M. (2001) "The social responsibility of business is to increase its profits", In T. L. Beauchamp \& N. E. Bowie (Eds.), Ethical theory and business, London: Prentice Hall

Friedman, M. (2002) Capitalism and freedom, Chicago: The University of Chicago Press

Gillham, B. (2000) Research Interviews, London: Continuum International Publishing Group

Gillis, A. \& Jackson, W. (2002) Research for Nurses: Methods and Interpretation, FA Davis Company

Golyagina, A., \& Valuckas, D. (2016) Representation of knowledge on some management accounting techniques in textbooks, Accounting Education, vol. 25(5): 479-501

Haniffa, R., Hudaib, M. \& Mirza, A. M. (2004) "Accounting Policy Choice within the Shariah Islamiiah Framework", Discussion Papers in Accountancy and Finance, SOBE, University of Exeter, 19 February

Helliar, C. (2013) "The global challenge for accounting education", Accounting Education, vol. 22(6): 510-521

Hu, C., Chand, P., \& Evans, E. (2013) "The effect of national culture, acculturation, and education on accounting judgments: A comparative study of Australian and Chinese culture", Journal of International Accounting Research, vol. 12(2): 51-77

International Accounting Standards Committee Foundation (IASCF) (1989), Framework for the Preparation and Presentation of Financial Statements, IASCF, London.

Ismail, F. (1995) Islam, Politics and Ideology in Indonesia: A Study of the Process of Muslim Acceptance of the Pancasila, (PhD), Institute of Islamic Studies, McGill University

Jensen, M. C. \& Meckling, W. H. (1976) "Theory of the firm: Managerial behavior, agency costs and ownership structure", Journal of Financial Economics, vol. 3(4): 305-360 
Jones, M. J. (2010) "Accounting for the environment: Towards a theoretical perspective for environmental accounting and reporting", Accounting Forum, vol. 34(2) 123-138

Kamla, R. \& Haque, F. (2017) "Islamic accounting, neo-imperialism and identity staging: The Accounting and Auditing Organization for Islamic Financial Institutions", Critical Perspectives on Accounting, in press, https://doi.org/10.1016/j.cpa.2017.06.001.

Kamla, R., Gallhofer, S. \& Haslam, J. (2006) "Islam, nature and accounting: Islamic principles and the notion of accounting for the environment', Accounting Forum, vol. 30(3): 245-265

Kamla, R., Gallhofer, S. \& Haslam, J. (2012) "Understanding Syrian accountants' perceptions of, and attitudes towards, social accounting", Accounting, Auditing \& Accountability Journal, vol. 25(7): 1170-1205

Kelly, P. T. (2017) "Integrating Leadership Topics into an Accounting Ethics Course-Preparing Students for a Challenging Profession", In Advances in Accounting Education: Teaching and Curriculum Innovations, Emerald Publishing, pp. 141-180

Lail, B., MacGregor, J., Marcum, J. \& Stuebs, M. (2017) "Virtuous professionalism in accountants to avoid fraud and to restore financial reporting", Journal of Business Ethics, vol. 140(4): 687-704

Lewis, M. K. (2001) "Islam and accounting", Accounting Forum, vol. 25(2): $103-127$

Melé, D., Rosanas, J. M. \& Fontrodona, J. (2017) "Ethics in Finance and Accounting: Editorial Introduction", Journal of Business Ethics, vol. 140(4): 609-613

Morfit, M. (1981) "Pancasila: the Indonesian state ideology according to the New Order government", Asian Survey, vol. 21(8): 838-851

Saravanamuthu, K. \& Tinker, T. (2008) "Ethics in education: The Chinese learner and post-Enron ethics", Critical Perspectives on Accounting, vol. 19(2): $129-137$

Sikka, P., Haslam, C., Kyriacou, O. \& Agrizzi, D. (2007) "Professionalizing claims and the state of UK professional accounting education: some evidence", Accounting Education: An International Journal", vol. 16(1): 3-21

Sorensen, D. P., Miller, S. E., \& Cabe, K. L. (2017) "Developing and measuring the impact of an accounting ethics course that is based on the moral philosophy of Adam Smith", Journal of Business Ethics, vol. 140(1): 175-191

Stevenson, L., Power, D., Ferguson, J. \& Collison, D. (2018) "The development of accounting in UK Universities: An oral history", Accounting History, vol. 23: 117-137

Vermaelen, T. (2009) "Maximizing shareholder value: An ethical responsibility?", In N. C. Smith \& G. Lenssen (Eds.), Mainstreaming corporate responsibility, Chichester: Wiley, pp. 206-218

Wells, P. K. (2018) "How well do our introductory accounting text books reflect current accounting practice?", Journal of Accounting Education, in press https://doi.org/10.1016/j.jaccedu.2017.12.003 